\title{
Pengembangan Bahan Ajar IPA Terpadu Berbasis Android Berorientasi Keterampilan Berpikir Kritis
}

\author{
Hilda Maulida ${ }^{\# 1}$, Parlindungan Sinaga ${ }^{* 2}$, Susilawati ${ }^{\# 3}$ \\ Pendidikan IPA Universitas Pendidikan Indonesia, Setiabudi, Bandung, \\ Pendidikan IPA Universitas Pendidikan Indonesia, Setiabudi, Bandung, \\ Pendidikan IPA Universitas Pendidikan Indonesia, Setiabudi, Bandung \\ ${ }^{1}$ hildamaulida@student.upi.edu \\ 2 P.sinaga@upi.edu \\ ${ }^{3}$ susi. lawaty23.23@gmail. com
}

\begin{abstract}
The results of the preliminary study show that students have low critical thinking skills. Teaching materials have an important role in learning. Learning cannot be done without teaching materials. This study aims to (1) develop teaching materials in the form of android applications with the development model of the Teaching Material Writing Process Model (MPM2A), (2) determine the feasibility of teaching materials, (3) the effectiveness of teaching materials in improving students' critical thinking skills. This type of research is research and development $(\mathrm{RnD})$ and to test the effectiveness of teaching materials. This study uses the Quasi Experiment design using pretest-posttest control group design in one of the state junior high schools in the city of Bandung. The study sample consisted of 64 students. With 32 students in the experimental class and 32 students in the control class. Research results 1) based on the feasibility test of teaching materials developed appropriate for use in learning activities. 2) teaching materials can improve critical thinking skills in the medium category 3) a measure of the effect size that teaching materials developed are effective in improving critical thinking skills
\end{abstract}

Keywords: Teaching materials, Android, Integrated Science, Critical Thinking Skills

\begin{abstract}
Abstrak - Hasil studi pendahuluan memperlihatkan bahwa siswa memiliki keterampilan berpikir kritis yang rendah. Bahan ajar memiliki peranan penting dalam pembelajaran. Pembelajaran tidak dapat dilakukan tanpa bahan ajar. Penelitian ini bertujuan untuk (1) mengembangkan bahan ajar dalam bentuk aplikasi android dengan model pengembangan Model Proses Menulis Materi Ajar (MPM2A), (2) mengetahui kelayakan bahan ajar, (3) keefektifan bahan ajar dalam meningkatkan keterampilan berpikir kritis siswa. Jenis penelitian ini adah penelitian dan pengembangan $(\mathrm{RnD})$ dan untuk menguji keefektifan bahan ajar Penelitian ini menggunakan desain Quasi Eksperimen dengan menggunakan pretest-posttest control group design di salah satu SMP Negeri di Kota Bandung. Sampel penelitian terdiri atas 64 siswa. Dengan 32 siswa kelas eksperimen dan 32 siswa kelas kontrol. Hasil penelitian 1) berdasarkan uji kelayakan bahan ajar yang dikembangkan layak untuk digunakan dalam kegiatan pembelajaran. 2) bahan ajar dapat meningkatkan keterampilan berpikir kritis pada kategori sedang 3) ukuran dari effect size bahwa bahan ajar yang dikembangkan efektif dalam meningkatkan keterampilan berpikir kritis.
\end{abstract}

Kata kunci: Bahan ajar, Android, IPA Terpadu, Keterampilan Berpikir Kritis

\section{Pendahuluan}

Perkembangan ilmu pengertahuan dan teknologi telah membawa perubahan yang sangat signifikan terhadap berbagai dimensi kehidupan manusia, baik ekonomi, sosial, budaya maupun pendidikan. Oleh karena itu agar pendidikan tidak tertinggal dari perkembangan iptek tersebut perlu adanya penyesuaian-penyesuian. Selain itu perkembangan ilmu pengetahuan dan teknologi semakin mendorong upaya-upaya pembaharuan dalam pemanfaatan hasil-hasil teknologi dalam 
proses belajar. Misalnya hasil dari perkembangan teknologi saat ini adalah smartphone android. Saat ini hampir seluruh siswa menggunakan android sebagai kebutuhan pokoknya. Android memiliki dampak positif dan negatif bagi siswa jika tidak dioptimalkan fungsinya maka akan banyak dampak negatifnya.

Dalam kegiatan pembelajaran terdapat beberapa komponen meliputi: tujuan, bahan ajar, penilaian, metode dan alat/media. Komponen tersebut tidak berdiri sendiri tetapi saling berhubungan dan mempengaruhi satu sama lain. Penggunaan bahan ajar merupakan salah satu komponen penting dalam proses pembelajaran di kelas. Oleh karna itu bahan ajar harus dikemas dengan menarik dan mampu mempengaruhi proses belajar siswa menjadi lebih baik. Hal ini merupakan salah satu tanggung jawab pendidik untuk mengemas bahan ajar yang mampu menarik minat siswa dalam kegiatan belajar. Dalam kurikulum 2013 peran guru dalam aktivitas pembelajaran tidak hanya menyampaikan ilmu pengetahuan tetapi juga memainkan berbagai peran yang bertujuan untuk mengembangkan potensi peserta didik secara optimal.

Berdasarkan peraturan menteri pendidikan nasional No. 22 tahun 2006 tentang standar isi dan peraturan menteri pendidikan nasional No.41 tahun 2007 tentang standar proses satuan pendidikan dasar dan menengah, "Isi kurikulum dituntut untuk mampu mendorong siswa agar dapat memanfaatkan TIK secara tepat untuk mencari informasi seluas dan mendalam mengenai topik yang dipelajari". Seperti diamanatkan UNESCO yaitu : "Learn to use ICT dan use ICT to learn" ( Unesco Toolkit ICT, 2009). Berdasarkan hal tersebut, bahan ajar yang ada saat ini masih perlu dikembangkan agar dapat memenuhi beberapa karakteristik yang disebutkan sebagai ciri-ciri bahan ajar yang masih belum dikembangkan secara optimal. Saat ini bahan ajar masih berupa buku, modul ataupun LKS dan dengan perkembang teknologi telah muncul bahan ajar berupa E-Learning ataupun Computer Based Material sebagai bahan ajar yang lebih komunikatif dan fleksibel. Namun masih banyak kekurangan yang belum terpenuhi dalam perkembangan bahan ajar tersebut sehingga bahan ajar masih dapat dikembangkan oleh guru untuk memenuhi kebutuhan dalam pembelajaran (Mahmud Kantar, 2015).
Saat ini pendidiikan abad 21 menuntut siswa untuk memiliki keterampilan seperti keterampilan berpikir kritis, pemecahan masalah, metakognisi, keterampilan berkomunikasi, berkolaborasi, inovasi dan kreasi, literasi informasi, dan berbagai keterampilan lainnya. Pencapaian keterampilan abad ke-21 tersebut dilakukan dengan memperbarui kualitas pembelajaran, membantu siswa mengembangkan partisipasi, menyesuaikan personalisasi belajar, menekankan pada pembelajaran berbasis proyek/masalah, mendorong kerjasama dan komunikasi, meningkatkan keterlibatan dan motivasi siswa, membudayakan kreativitas dan inovasi dalam belajar, menggunakan sarana belajar yang tepat, mendesain aktivitas belajar yang relevan dengan dunia nyata, memberdayakan metakognisi, dan mengembangkan pembelajaran studentcentered. Berbagai keterampilan abad ke-21 harus secara eksplisit diajarkan. Secara singkat, pembelajaran abad ke-21 memiliki prinsip pokok bahwa pembelajaran harus berpusat pada siswa, bersifat kolaboratif, kontekstual, dan terintegrasi dengan masyarakat. Peran guru dalam melaksanakan pembelajaran abad ke-21 sangat penting dalam mewujudkan masa depan anak bangsa yang lebih baik

Pengembangan bahan ajar berbentuk ebook yang tersedia saat ini masih dalam bentuk memindahkan buku dalam bentuk digital serta belum maksimal untuk melatihkan keterampilan tertentu seperti tuntutan pendidikan pada abad 21. Oleh karena itu perlu adanya pengembangan bahan ajar berbasis android untuk mengoptimlakan fungsi dari kemajuan teknologi saat ini. Pengembangan bahan jar yang dikembangkan harus disertai dengan melatihkan keterampilan tertentu agar pendidikan abad 21 terpenuhi. Sehingga dapat mewujudkan masa depan bangsa yang lebih baik.

\section{LANDASAN TEORI}

\section{Model pengembangan bahan ajar}

Model pengembangan bahan ajar yang digunakan dalam penelitian ini adalah Model Proses Menulis Materi Ajar (MPM2A) yang dikembangkan oleh Sinaga (2015). Berikut ini penjelasan sintaks pengembangannya:
a. Menganalisi kurikulum IPA untuk SMP
b. Membuat tujuan penulisan
c. Menentukan cakupan materi
d. Daftar garis besar konsep pertama 
e. Pembuatan peta konsep

f. Membuat garis besar konsep final yang sudah direvisi

g. Membuat multimodus representasi

h. Menulis draf materi ajar

i. Mengevaluasi apakah tujuan penulisan terpenuhi

j. Melakukan reviu dan pengeditan

k. Melakukan uji keterbacaan atau uji ide pokok wacana dan uji kualitas tulisan bahan ajar berbasis aplikasi android.

\section{Keterampilan Berpikir Kritis}

Berpikir merupakan proses yang dilakukan otak dalam menerima informasi dari indera yang didapat dari pengalaman dan didasari oleh suatu pola yang logis. Abdullah dan Shariff (2008) mendefinisikan kemampuan berpikir adalah serangkaian kemampuan mental atau pola pemikiran yang rasional dan logik. Kemampuan berpikir manusia menentukan bagaimana seseorang memecahkan masalah, membuat keputusan dan memahami sesuatu. Pada konteks pembelajaran IPA, kemampuan ini diperlukan siswa untuk memahami persoalan yang ditemui di alam dan memahami proses terjadinya hal tersebut.

Brink dan Budgen (2007) berpikir kritis adalah sebuah proses reaksi, kemampuan seseorang untuk merangkai sebuah kesimpulan dan beberapa alasan untuk suatu kejadian. Menurut Ennis (2013) berpikir kritis adalah aktivitas mental dalam mengevaluasi suatu argumen atau proposisi dan membuat keputusan yang dapat menuntun diri seseorang dalam mengembangkan kepercayaan dan melakukan tindakan, selama tingkat berpikir kritis rendah akan berpengaruh terhadap keberhasilan dalam area-area yang memerlukan berpikir kritis. Johnson (2002) mengemukakan kemampuan berpikir kritis disebut juga sebagai kemampuan berpikir tingkat tinggi. Liliasari dan Redhana (2007) menyatakan bahwa kemampuan berpikir kritis berkaitan dengan kemampuan mengidentifikasi, menganalisis dan memecahkan masalah secara kreatif sehingga menghasilkan pertimbangan dan keputusan yang tepat.

Pentingnya kemampuan berpikir kritis dikemukakan pula oleh Lambertus (2009) berpikir kritis dapat membantu seseorang memahami bagaimana ia memandang dirinya sendiri, bagaimana ia memandang dunia, dan bagaimana ia berhubungan dengan orang lain, membantu meneliti prilaku diri sendiri, dan menilai diri sendiri. Berpikir kritis memungkinkan seseorang menganalisis pemikiran sendiri untuk memastikan bahwa ia telah menentukan pilihan dan menarik kesimpulan cerdas. Sedangkan orang yang tidak berpikir kritis, ia tidak dapat memutuskan untuk dirinya sendiri apa yang harus dipikirkan, apa yang harus dipercaya dan bagaimana harus bertindak. Karena gagal berpikir mandiri, maka ia akan meniru orang lain, mengadopsi keyakinan dan menerima kesimpulan orang lain dengan pasif. Peningkatan kemampuan berpikir kritis siswa sangat diperlukan terutama dalam pembelajaran IPA, memberikan bekal yang baik dalam mengambil suatu keputusan berdasarkan interpretasi, analisis dan evaluasi suatu fenomena dalam memecahkan masalahmasalah di kehidupan nyata. Ennis (2013) membagi indikator kemampuan berpikir kritis menjadi lima indikator yaitu
1) Memberikan penjelasan sederhana
2) Membangun keterampilan dasar
3) Menyimplkan
4) Memberikan penjelasan lanjut
5) Strategi dan taktik

\section{Bahan Ajar IPA Terpadu}

Secara bahasa, terpadu berarti sudah dipadu, disatukan, dilebur menjadi satu, dan sebagainya (KBBI Online, 2018). IPA berdasarkan objek kajian ilmunya, terdiri atas biologi, fisika, dan kimia. Dengan demikian, IPA terpadu berarti memadukan, menyatukan, atau melebur kajian-kajian biologi, fisika, dan kimia dalam kegiatan pembelajaran IPA dengan mengacu pada kurikulum yang berlaku serta tidak menutup kemungkinan untuk memadukan pembelajaran IPA dengan bidang ilmu lainnya, seperti ekonomi, geografi dan lainnya.

Menurut Fogarty (1991) terdapat sepuluh cara memadukan kurikulum yaitu sebagai berikut:

a. Model fragmen merupakan penyajian masing-masing disiplin ilmu secara terpisah dan dibahas secara mendalam.

b. Model terhubung merupakan penyajian disiplin ilmu tertentu yang dibahas dengan cara menghubungkan antartopik atau antarkonsep secara eksplisit.

c. Model tersarang merupakan penyajian disiplin ilmu dengan melatihkan keterampilan-keterampilan tertentu. 
d. Model terurut merupakan penyajian konten antardisiplin ilmu yang disusun secara berurutan.

e. Model terbagi merupakan penyajian konten antardisiplin ilmu dimana konsep yang berkaitan dibahas secara bersamaan.

f. Model jaring laba-laba merupakan penyajian materi pelajaran dalam bentuk tema.

g. Model pasang benang merupakan pembelajaran yang melatihkan keterampilan tertentu melalui berbagai disiplin ilmu.

h. Model integrasi merupakan pembelajaran yang meleburkan baik sikap, konsep, keterampilan, maupun prioritas kurikulum.

i. Model terbenam merupakan keterpaduan yang dilakukan oleh pembelajar secara internal dan intrinsik dengan sedikit intervensi dari lingkungan.

j. Model jaringan merupakan keterpaduan yang dilakukan oleh pembelajar secara mandiri dalam dirinya.

Pembelajaran IPA Terpadu merupakan pembelajaran yang erat dengan pengalaman sesungguhnya. Pembelajaran IPA mempelajari konsep-konsep yang berhubungan dengan fenomena yang dekat dengan kehidupan seharihari peserta didik. Sejalan dengan hal tersebut, (Kemendikbud, 2016a) menyatakan bahwa proses pembelajaran IPA di Sekolah Menengah Pertama (SMP) dilaksanakan secara tematik terpadu. Pembelajaran tematik terpadu merupakan pembelajaran yang memadukan dua atau lebih bidang IPA dalam suatu kegiatan pembelajaran. Pemaduan dilakukan dengan menekankan pada prinsip keterkaitan antar bidang IPA mengingat bahwa semua fenomena alam yang terjadi selalu melibatkan dua atau lebih bidang IPA. Pelaksanaan pembelajaran IPA secara tematik terpadu diharapkan terjadi peningkatan pemahaman yang lebih bermakna dan peningkatan wawasan karena satu pembelajaran melibatkan lebih dari satu cara pandang (Rustaman dkk., 2005).

\section{METODE PENELITIAN}

Jenis penelitian ini adalah penelitian dan pengembangan, Desain penelitian untuk menguji keefektifan digunakan pretest-posttest control group design. Penelitian ini menggunakan kelompok eksperimen dan kelompok kontrol yang dipilih secara acak. Kelompok eksperimen menggunakan bahan ajar yang dikembangkan dan kelompok kontrol menggunakan bahan ajar yang biasa digunakan di sekolah. Terhadap dua kelompok dilakukan pretest dan posttest untuk melihat keterampilan berpikir kritis siswa sebelum dan setelah menggunakan bahan ajar yang dikembangkan.

Populasi dalam penelitian ini yaitu kelas VII tahun ajaran 2018/2019 disalah satu SMP Negeri di kota Bandung.sampel yang ambil yaitu dua kelas VII yaitu satu kelas kontrol dan satu kelas eksperimen dengan teknik purpose sampling.

Pada penelitian ini aspek yang dinilai adalah kualitas bahan ajar yang berupa angket penilaian dan peningkatan keterampilan berpikir kritis yang dihitung menggunakan effect size. Tes keterampilan berpikir kritis berupa soal pilihan ganda yang terdiri dari 20 soal dengan indikator berpikir kritis yakni dengan menggunakan 5 aspek keterampilan menurut Ennis, R. H (1985) 1) memberikan penjelasan sederhana 2) membangun keterampilan dasar 3) menyimpulkan 4) klarifikasi lanjut 5) strategi dan taktik.

\section{PEMBAHASAN}

Instrumen yang digunakan adalah angket penilaian kualitas bahan ajar. Angket tersebut diajukan kepada dosen dan guru dengan melampirkan produk bahan ajar IPA terpadu yang dikembangkan. Penilaian kualitas bahan ajar dilakukan oleh 10 guru dan 3 dosen IPA.

Berdasarkan hasil penilaian kualitas bahan ajar dari 13 validator menilai bahan ajar yang dikembangkan memiliki kualitas yang sangat baik, sedangkan 6 lainnya menilai bahan ajar yang dikembangkan memiliki kualitas yang terkategori baik. Rata-rata secara keseluruhan kualitas bahan ajar yang dikembangkan dinilai pada kategori baik.

Penilaian kualitas bahan ajar menilai beberapa aspek, yaitu kesesuaian kurikulum, keterpaduan, kemutakhiran konten, aturan penulisan, keterampilan yang dilatihkan, serta kedalaman dan keluasan materi. Ditinjau dari aspek-aspek tersebut, ringkasan hasil penilaian kualitas bahan ajar dapat dilihat pada Gambar 1 


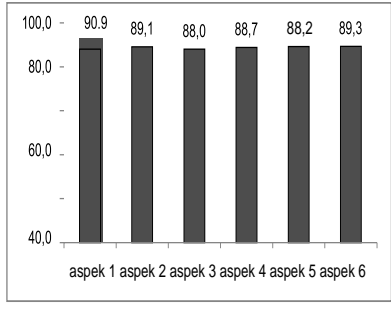

Gambar1. Hasil Penilaian Kualitas Bahan Ajar dari Berbagai Aspek

Keterangan:

Aspek 1 : Kesesuaian kurikulum

Aspek 2 : Keterpaduan konten IPA

Aspek 3 : Kemutakhiran konten

Aspek 4 : Aturan penulisan

Aspek 5 : Keterampilan yang dilatihkan

Aspek 6 : Keluasan dan kedalaman materi

Berdasarkan hasil penilaian kualitas bahan ajar yang disajikan pada Gambar 4.5, aspek-aspek yang dinilai oleh para validator tidak memiliki perbedaan yang cukup jauh, berada pada kisaran $88-89 \%$. Rata-rata secara keseluruhan kualitas bahan ajar yang dikembangkan jika ditinjau dari aspek yang dinilai berada pada kategori baik.

Peningkatan keterampilan berpikir kritis siswa dapat diketahui setelah bahan ajar yang dikembangkan dan diimplementasikan dalam pembelajaran.

Pengimplementasian bahan ajar dilakukan setelah bahan ajar layak untuk digunakan. Data peningkatan keterampilan berpikir kritis diperoleh dari hasil tes keterampilan berpikir kritis yang dilakukan di awal dan di akhir pembelajaran pada kelas eksperimen dan kontrol. Peningkatan kemampuan keterampilan berpikir kritis siswa dapat dilihat dari hasil pretest dan posttest yang telah didapatkan yang kemudian dihitung dengan rata-rata skor gain yang dinormalisasi $\langle\mathrm{g}\rangle$. Peningkatan kemampuan kognitif siswa dapat dilihat pada tabel 1 di bawah

Tabel 1 Peningkatan Keterampilan Berpikir Kritis Siswa Kelas Kontrol dan Eksperimen

\begin{tabular}{|c|c|c|c|c|}
\hline \multirow[t]{2}{*}{ Kelas } & \multicolumn{3}{|c|}{ Rata-rata } & \multirow[t]{2}{*}{ ket } \\
\hline & $\begin{array}{l}\text { Pretes } \\
\mathrm{t}\end{array}$ & $\begin{array}{l}\text { posttes } \\
\mathrm{t}\end{array}$ & nGain & \\
\hline $\begin{array}{l}\text { Eksperime } \\
\mathrm{n}\end{array}$ & 9,43 & $\begin{array}{l}53,6 \\
7\end{array}$ & $\begin{array}{l}0,5 \\
1\end{array}$ & $\begin{array}{l}\text { Sedan } \\
\mathrm{g}\end{array}$ \\
\hline Kontrol & 1,95 & $\begin{array}{l}66,9 \\
3\end{array}$ & $\begin{array}{l}0,6 \\
9\end{array}$ & $\begin{array}{l}\text { Sedan } \\
\mathrm{g}\end{array}$ \\
\hline
\end{tabular}

Dari tabel 1 diketahui bahwa kedua kelas mengalami peningkatan keterampilan berpikir kritis. Besarnya peningkatan tersebut dapat dilihat dari nilai $n$-gain kedua kelas, yaitu 0,51 untuk kelas kontrol dan 0,69 untuk kelas eksperimen, dengan masing-masing kelas berada pada kategori sedang. Namun, besarnya peningkatan keterampilan berpikir kritis kelas eksperimen berbeda dengan kelas kontrol. Peningkatan keterampilan berpikir kritis kelas eksperimen lebih besar dibandingkan kelas control

Keefektifan bahan ajar IPA terpadu yang dikembangkan dapat ditentukan dengan menguji hipotesis secara statistik dan menentukan ukuran dampak (effect size). Uji hipotesis dilakukan menggunakan program SPSS 16. Data yang digunakan adalah data skor rata-rata peningkatan keterampilan berpikir kritis kelas eksperimen dan kelas kontrol. Dengan menguji normalitas dan homogenitas kedua kelas telebih dahulu. Uji hipotesis peningkatan keterampilan berpikir kritis siswa menggunakan uji statistik parametrik, yaitu uji t. Ringkasan hasil uji hipotesis data peningkatan keterampilan berpikir kritis disajikan pada Tabel 2

Tabel 2 Hasil Uji Hipotesis Data

Peningkatan Keterampilan Berpikir Kritis

\begin{tabular}{|l|r|l|l|}
\hline t & df & Sig. (2-tailed) & $\begin{array}{l}\text { Keput } \\
\text { usan }\end{array}$ \\
\hline- & 68 & 0,000 & $\begin{array}{l}\mathrm{H}_{0} \\
5,5\end{array}$ \\
53 & & & ditolak \\
\hline
\end{tabular}

Data peningkatan keterampilan berpikir kritis yang disajikan pada Tabel 2 memiliki nilai probabilitas $($ Sig. $)=0,000<\alpha=$ 0,05 sehingga $\mathrm{H}_{0}$ ditolak. Dengan demikian, dapat disimpulkan bahwa bahan ajar IPA terpadu yang dikembangkan lebih meningkatkan secara signifikan keterampilan berpikir kritis daripada bahan ajar IPA terpadu yang biasa digunakan.

Analisis ukuran dampak bertujuan untuk mengetahui besarnya pengaruh penggunaan bahan ajar IPA terpadu yang dikembangkan terhadap keterampilan berpikir kritis. Ukuran dampak ditentukan menggunakan kriteria Cohen. Hasil analisis ukuran dampak penggunaan bahan ajar yang dikembangkan terhadap keterampilan berpikir kritis disajikan pada Tabel 3 
Tabel 3 Hasil Analisis Ukuran Dampak Bahan Ajar yang

Dikembangkan

\begin{tabular}{|l|l|l|l|l|l|l|}
\hline $\mathbf{M E}_{\mathbf{E}}$ & $\mathbf{M C}_{\mathbf{C}}$ & SDE $_{\mathbf{E}}$ & SDC $_{\mathbf{C}}$ & SDpool $_{\text {p }}$ & $\begin{array}{l}\text { Krite } \\
\text { ria }\end{array}$ \\
\hline 0,40 & 0,21 & 0,15 & 0,14 & 0,14 & $\begin{array}{l}1,3 \\
3\end{array}$ & Besar \\
\hline
\end{tabular}

Berdasarkan Tabel 3, koefisien ukuran dampak bahan ajar yang dikembangkan terhadap keterampilan berpikir kritis sebesar 1,33 dengan kriteria besar (large effect). Hal ini berarti penggunaan bahan ajar IPA terpadu yang dikembangkan memiliki dampak yang besar dalam meningkatkan keterampilan berpikir kritis dibandingkan bahan ajar yang biasa digunakan di sekolah. Berdasarkan uji hipotesis secara statistik dan ukuran dampak, dapat disimpulkan bahwa bahan ajar IPA terpadu efektif dalam meningkatkan keterampilan berpikir kritis dibandingkan bahan ajar yang biasa digunakan di sekolah

\section{KESIMPULAN}

Berdasarkan hasil analisis data penelitian yang telah dipaparkan sebelumnya, maka dapat disimpulkan beberapa hal, yaitu sebagai berikut:

1. Penilaian kualitas bahan ajar yang termasuk dalam kategori baik dan uji keterpahaman yang menunjukkan siswa dapat memahami bahan ajar secara mandiri menyimpulkan bahwa bahan ajar yang dikembangkan layak untuk digunakan.

2. Peningkatan keterampilan berpikir kritis siswa yang menggunakan bahan ajar IPA terpadu yang dikembangkan termasuk dalam kriteria sedang.

3. Bahan ajar yang dikembangkan efektif dalam meningkatkan keterampilan berpikir kritis siswa karena memiliki dampak yang besar dan secara signifikan lebih meningkatkan keterampilan berpikir kritis siswa.

\section{DAFTAR PUSTAKA}

[1] Abdullah, S. dan Shariff, A. (2008), “ The Effect of Inquiry-Base Computer Simulation with Cooperative Learning on Scientific Thinking and Conceptual Understanding of Gas Law” Eurasia
Journal of Mathematics Science, and Tecnology Education. 4, (4), 387-398

[2] Ennis, R.H. 1985. Goals for A Critical Thiking Curriculum. Costa, A.L. (Ed). Developing Minds A Resource Book for Teaching Thinking. Alexandra, Virginia: Assosiation for Supervisions and Curriculum Development (ASCD).

[3] Fogarty, Robin. 1991. How to Integrated the Curricula. Palatine, Ilinois: IRI/ Skylight Publishing, Inc.

[4] Johnson David W and Roger T. Johnson. 2002. Cooperative Learning Methode: A Meta-Analysis. Journal of ResearchEducation.http://www.eeraon line.org/journal/files/2002/JRE_2002_ 01_DWJohnson. pdf

[5] Kemendikbud.(2016).Permendikbud No 020 tahun 2016 Tentang Standar Kompetensi Lulusan Pendidikan DasarDan Menengah. Jakarta:kemendikbud.

[6] Lambertus (2009) pentingnya melatih keterampilan berpikir kritis dalam pembelajaran matematika di SD (jurnal Forum Kependidikan Nomor 2 Volume 84 Maret 2009). Kendari:

FKIP Unhalu

[7] Rustaman dkk.,(2005). Strategi Melajar dan Mengajar Biologi. Malang : Press

[8] Redhana, I.W. dan Liliasari. 2008. Program Pembelajaran Keterampilan Berpikir Kritis Pada Topik Laju Reaksi Untuk Siswa SMA. Diakses tanggal 30 Desember 2011.

[9] Sinaga, P., KAniawati, I., SetiawanA. (2017). Improving Secondary School Student Scientific Litercy Ability Through The Design Of Better Science Textbook. Journal of Turkish Science Education, 14 (4), 92-107

[10] UNESCO. 2002. Information and Communication Technology in Education: A Curriculum for Schools and Programme of Teacher Development (Eds J. Anderson and T. 
p-ISSN : 2460-7363

e-ISSN : 2614-6606

van Weert). UNESCO, Paris. [Online].

http://unesdoc.unesco.org/images/

0012/ 001295/129538e.pdf [diakses:

13 Februari 2014]berdasarkan-unesco-

ictcompetency-framework-teachers/

-- Jurnal PETIK Volume 5, Nomor 1, Maret 2019-- 76 